\title{
THE EFFECT OF MATRIX MORPHOLOGY ON DYNAMIC-MECHANICAL PROPERTIES OF POLYPROPYLENE/LAYERED SILICATE NANOCOMPOSITES
}

\author{
Luljeta Raka $^{1}$, Gordana Bogoeva-Gaceva ${ }^{2,3 *}$, Andrea Sorrentino ${ }^{4}$ \\ ${ }^{1}$ Faculty of Natural Sciences and Mathematics, State University of Tetovo, \\ Bul. Ilinden, 1200 Tetovo, Republic of Macedonia \\ ${ }^{2}$ Faculty of Technology and Metallurgy, Ss Cyril and Methodius University, \\ Rudjer Bošković 16, 1000 Skopje, Republic of Macedonia \\ ${ }^{3}$ Research Center for Environmental and Materials, Macedonian Academy of Sciences and Arts, \\ Bul. Krste Misirkov 2, 1000 Skopje, Republic of Macedonia \\ ${ }^{4}$ Institute for Polymers, Composites and Biomaterials (IPCB-CNR), Piazzale Enrico Fermi 1, \\ Portici, 80055 Napoli, Italy \\ gordana@tmf.ukim.edu.mk
}

In this work, the influence on the morphology and viscoelastic behavior of polypropylene/clay nanocomposites of clay, in combination with different crystallization rates applied in compression molding, is reported. By deconvolution of differential scanning calorimetry (DSC) melting endotherms, it was found that the slowly cooled samples had slightly higher melting temperatures, and the crystal dimensions decreased progressively with the clay content; while, in contrast, the presence of clay particles had no influence on the crystal dimensions in fast-cooled samples. Dynamic mechanical thermal analysis (DMTA) has shown that above the glass transition temperature, nanocomposites obtained by slow cooling exhibited better mechanical response compared to the fast-cooled samples. The value of dynamic modulus $E$ ' of slow-cooled samples increased by $\sim 55 \%$ with addition of only $1 \mathrm{wt} \%$ clay, which was attributed to the better reinforcing effect achieved during prolonged time of crystallization.

Keywords: polypropylene; clay; nanocomposites; morphology; DMTA

\section{ВЛИЈАНИЕ НА МОРФОЛОГИЈАТА НА МАТРИЦАТА ВРЗ ДИНАМИЧКО-МЕХАНИЧКИТЕ СВОЈСТВА НА НАНОКОМПОЗИТИТЕ ПОЛИПРОПИЛЕН/СЛОЕВИТИ СИЛИКАТИ}

Во овој труд е испитувано влијанието на глината врз морфологијата и вискоеластичните својства на нанокомпозитите полипропилен/глина добиени со пресување при примена на различни брзини на кристализација. Со деконволуција на ендотермите од диференцијалната скенирачка калориметрија (DSC), констатирано е дека бавно ладените примероци се одликуваат со незначително повисока температура на топење, а димензиите на кристалитите се намалуваат со количеството додадена глина, спротивно на примероците нагло ладени, кај кои присуството на глина нема влијание на димензиите на кристалитите. Динамичко-механичката анализа (DMTA) покажа дека над температурата на стаклосување првите поседуваат подобри механички карактеристики. Динамичкиот модул на овие примероци се зголемува за 55 \% со додаток на само $1 \%$ глина, што се припишува на постигнатиот подобар ефект на зајакнување на матрицата при продолженото време на кристализацијата.

Клучни зборови: полипропилен; глина; нанокомпозити; морфологија; DMTA 


\section{INTRODUCTION}

The properties of thermoplastic polymeric materials, including polymer nanocomposites, are greatly affected by their morphology. Improvements in mechanical properties, dimensional stability, and electrical, barrier and thermal properties, as well as fire retardant enhancements [1-5] are often reported for polypropylene (PP) nanocomposites of different morphologies, caused by the presence of nanofillers such as carbon nanotubes [610], layered silicates [11-15], silica, graphite and calcium carbonate [16-19].

The studies on polymer-layered silicate nanocomposites have shown a significant change in the viscoelastic properties depending on the microstructure and the interfacial characteristics of the polymer systems [20-23]. Hoffmann et al. [20] and Lim and Park [21] reported that the linear viscoelastic properties of nanocomposites were greatly affected by the final dispersion state of clay in the polymer matrix. In particular, nanocomposites with the polymer chains end-tethered to the surface of the silicate showed significant change in viscoelastic properties [22, 23]. It was also reported that the mechanical properties of the composites are affected by both plasticization and exfoliation. At low weight fraction of compatibilizer, the exfoliation effect was more significant, thus leading to enhanced mechanical properties. However, the effect of exfoliation becomes less pronounced with higher amounts of compatibilizer, as the lowmolecular-weight compatibilizer plasticizes the matrix, thus reducing the modulus, even though the extent of delamination of the silicate is increased [24].

Dynamic mechanical analysis (DMA) has been extensively used to measure the response of a given material to a cyclic deformation as a function of temperature. A wide range of values for the storage modulus $\left(E^{\prime}\right)$, corresponding to the elastic response to the deformation, the loss modulus ( $\left.E^{\prime \prime}\right)$, corresponding to the plastic response to the deformation, and $\tan \delta$, which is the ratio of the elastic to loss modulus, have been reported for different polymer/clay systems [25-28]. The dynamic mechanical response of PP/clay nanocomposites has been analyzed by many authors. In most cases [29-39] it has been shown that the addition of nanoclays increases the storage modulus of the material. However, contradictory results were found with respect to the glass transition temperature; in most of these works, $T_{\mathrm{g}}$ was found to be practically unaffected by the presence of clays. An increase in $T_{\mathrm{g}}$ was reported for PP-based nanocomposites [35, 38], whereas on the contrary, significantly decreased $T_{\mathrm{g}}$ was reported in [39]. The characteristics of $\alpha, \beta$, and $\gamma$ relaxations, and the activation energy of $\beta$ relaxation of $\mathrm{PP}$ in $\mathrm{PP} /$ clay nanocomposites, have been analyzed by Velasco et al. [40]. It has been observed that $\alpha, \beta$, and $\gamma$ relaxations of PP depend strongly on the interaction between the different phases in the nanocomposites. In general, achievement of a predominantly exfoliated microstructure usually resulted in the greatest improvement of dynamic-mechanical properties (the highest storage modulus and the lowest loss factor values) [41].

The majority of the studies of PP/clay nanocomposites are focused on the fabrication methods and conditions of the composites, and on the properties affected by the distribution and size of the filler particles within the polymer matrix. Recently, a specially designed hyperbolical nozzle was used to induce elongational flow for better mechanical properties in injection molded PP/clay nanocomposites [42]. A novel one-pot preparation method of extrusion, combined with water injection, was proposed for high clay dispersion into a PP-gMAH matrix [43]. Water-assisted extrusion of $\mathrm{PP} /$ clay nanocomposites at different conditions, including high shear rates, was investigated [44, 45], and the best mechanical and thermal properties were achieved when the clay was mixed in the slurry state, due to the highest level of dispersion reached by the synergistic effect of water, and high shear rates [45]. The effect of multiple extrusions on the impact properties of $\mathrm{PP} /$ clay nanocomposites was investigated by Klitkou et al. [46]. Different conditions and equipment for extrusion and injection molding were proposed in the literature to alter the tensile strength and modulus, fatigue properties, and fracture and thermal behavior of PP/clay nanocomposites [47-53].

However, the effect of polymer crystalline structure developed under extremely different crystallization conditions of PP nanocomposites has, to our knowledge, been poorly investigated [54]. In our previous work we have shown that the melt extrusion of maleic anhydride-modified PP and organo-clay enables production of clay nanocomposites with both exfoliated and mixed exfoliated/intercalated structure, and that depending on the amount of clay and the processing conditions, the polymer exhibits different crystalline structure [55]. The goal of this research is to determine the morphological peculiarities and viscoelastic behavior of PP/clay nanocomposites produced via melt blending followed by (i) slow and (ii) fast cooling in the compression molding cycle. 


\section{EXPERIMENTAL}

\subsection{Materials}

The isotactic polypropylene (iPP) used as a matrix in the nanocomposites was a homopolymer (Borclean HB300BF, Borealis) with $M_{\mathrm{w}}=608 \mathrm{~kg}$ $\mathrm{mol}^{-1}, \mathrm{MFI}=2.5 \mathrm{~g} / 10 \mathrm{~min}\left(230^{\circ} \mathrm{C}, 2.16 \mathrm{~kg}\right)$ and a density of $0.91 \mathrm{~g} \mathrm{~cm}^{-3}$. It was kindly supplied by COST Action P12: WG3-Polymer Bank [www.unirostock.de/fakult/manafak/physik/poly/C OST_P12/]. Maleic anhydride grafted PP (PP-gMA, with MA content $=0.6 \mathrm{wt} \%, \mathrm{MFI}=115$ at $190{ }^{\circ} \mathrm{C} / 2.16 \mathrm{~kg}$ and a density of $0.95 \mathrm{~g} \mathrm{~cm}^{-3}$ ), supplied by Aldrich, was used as compatibilizer for promoting exfoliation of the organoclay, Cloisite C93A (Southern Clay Products, Inc), with a cationexchange capacity (CEC) of $90 \mathrm{meq} / 100 \mathrm{~g}$ clay, organically modified with ternary ammonium salt.

\subsection{Preparation of iPP/clay nanocomposites}

The preparation of nanocomposites is described in detail elsewhere [55-57]. Briefly, the first step was direct-melt mixing of the components (iPP, $10 \mathrm{w} / \mathrm{w} \%$ compatibilizer and $1-3 \mathrm{w} / \mathrm{w}$ $\%$ clay) in a recirculating co-rotating twin-screw micro-extruder, followed by compression-molding at $180{ }^{\circ} \mathrm{C}$ for $2 \mathrm{~min}$ with no applied pressure. After this period, a pressure of 100 bars was applied for 3 min. Then, by altering the cooling rate during compression molding, two types of nanocomposite samples were produced. The cooling rate of about $15{ }^{\circ} \mathrm{C} \min ^{-1}$ was achieved by cooling the press plate with water (samples assigned as fast-cooled, FC) and the rate of about $1{ }^{\circ} \mathrm{C} \mathrm{min}{ }^{-1}$ was attained by cooling down the samples outside the press to room temperature (samples assigned as slowcooled, SC); samples with 1, 2 and $3 \mathrm{w} / \mathrm{w} \%$ clay were assigned as $\mathrm{C} 1, \mathrm{C} 2$ and $\mathrm{C} 3$ nanocomposites, respectively. For further analyses by SEM/TEM, DSC and DMTA, nanocomposite films with thickness of 100-300 $\mu \mathrm{m}$ were produced.

\section{CHARACTERIZATION METHODS}

\subsection{Scanning electron microscopy (SEM)}

SEM analysis of PP/PP-g-MA/C93A composite was performed using a Quanta 3D FEG microscope (Fei Co.), equipped with a field-emission gun. High-vacuum conditions were applied and a secondary electron detector was used for image acquisition. No additional sample treatment, such as surface etching or coating with a conductive layer was applied before surface scanning.

\subsection{Transmission electron microscopy (TEM)}

The dispersion of the clay particles in the polymer matrix was checked by using TEM (Tecnai 20), operated in bright-field mode at $200 \mathrm{kV}$. Ultrathin sections of the samples, with a thickness of approximately $90 \mathrm{~nm}$, were prepared at room temperature using an ultramicrotome ReichertJung Ultracut E equipped with a diamond knife. The sections were transferred dry to carbon-coated $\mathrm{Cu}$ grids of 200 mesh.

\subsection{Differential scanning calorimetry}

The melting behavior of investigated samples was determined by differential scanning calorimetry (DSC). The DSC experiments were performed using a DSC-7 analyzer (Perkin Elmer). The samples, with a mass of about $5 \mathrm{mg}$, were heated from 25 to $200{ }^{\circ} \mathrm{C}$ at a heating rate of $10{ }^{\circ} \mathrm{C}$ $\min ^{-1}$ in inert nitrogen atmosphere. A curve-fitting analysis of the melting curves was carried out in order better to determine the overlapping peak positions and areas. Deconvolution was done by using a Gaussian function.

\subsection{Dynamic mechanical thermal analysis (DMTA)}

Dynamic mechanical analysis of neat PP and PP/PP-MA/clay nanocomposites was performed on a TA Instruments DMAQ800 machine, fitted with a tensile testing head, and corresponding viscoelastic properties were determined as a function of temperature. A rectangular strip was cut from the compression-molded films. The system was automatically cooled to $-50{ }^{\circ} \mathrm{C}$, and then heated at a rate of $3{ }^{\circ} \mathrm{C} \mathrm{min}^{-1}$ to $150{ }^{\circ} \mathrm{C}$ under nitrogen flow. The samples were scanned at fixed frequency of 1 $\mathrm{Hz}$ and amplitude of $10 \mu \mathrm{m}$. A static force of 10 $\mathrm{mN}$ was applied to ensure that the sample was taut between the tensile grips. The force was kept constant during the test to allow shrinkage of the sample during testing.

\section{RESULTS AND DISCUSSION}

\subsection{Morphological analysis}

As revealed by our previous WAXD analysis [55], different polymer morphologies of $\mathrm{PP} /$ clay nanocomposites are developed by altering the cooling rate in the compression molding cycle. 
Better intercalation has been achieved for nanocomposites produced by a slow cooling procedure, even in the absence of compatibilizer (PP-g-MA). Also, the extent of intercalation/exfoliation and stacking of the clay particles in the polymer matrix were controlled by the amount of clay, indicating formation of exfoliated (at low clay content, $1 \mathrm{w} / \mathrm{w}$
$\%$ ) and mixed intercalated/exfoliated structure (at higher clay content).

Figure 1 shows SEM images of the surface of PP/PP-MA/clay nanocomposite containing 1 and $3 \mathrm{w} / \mathrm{w} \%$ clay. Obviously, a good dispersion of clay was attained in both cases, without evidence of particle aggregation.
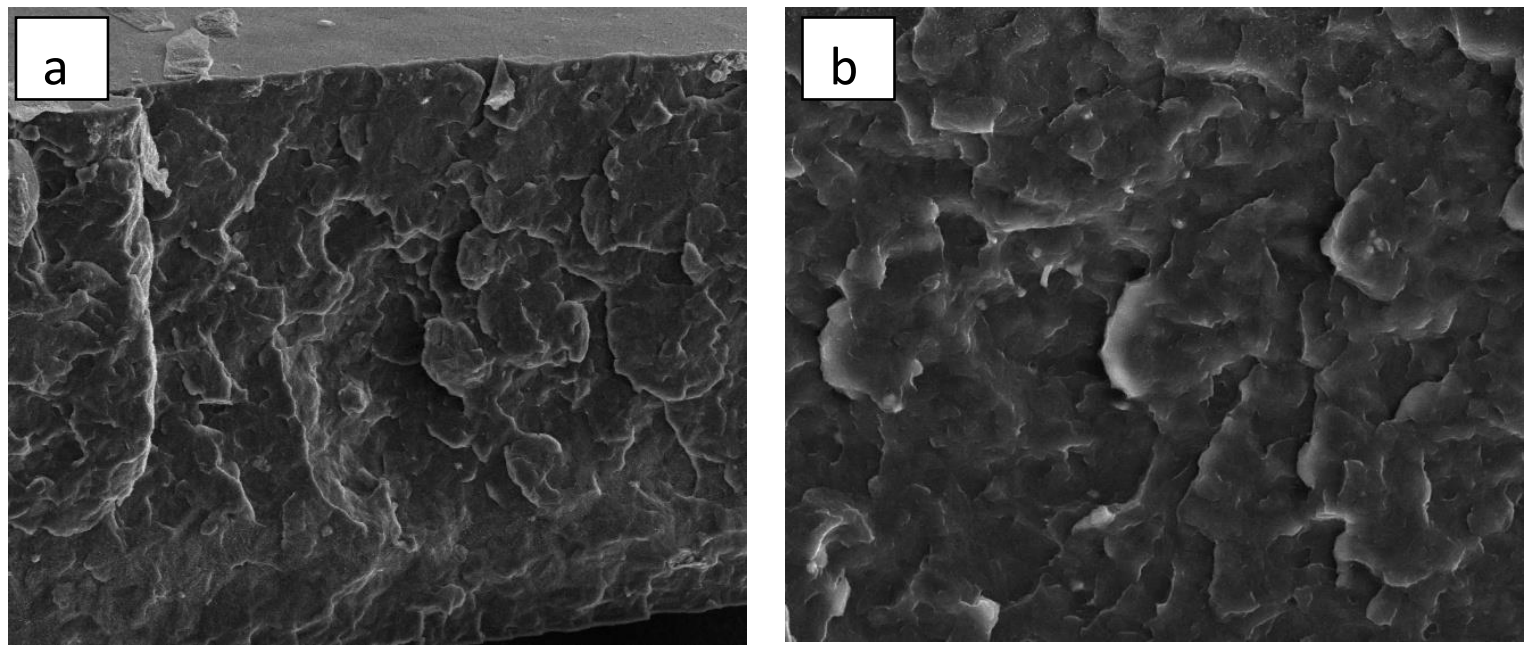

Fig 1. SEM micrographs of PP/PP-MA/clay nanocomposite with (a) $1 \mathrm{w} / \mathrm{w} \%$ and (b) $3 \mathrm{w} / \mathrm{w} \%$ clay

Figure 2 shows TEM bright-field images of the sample with $1 \mathrm{w} / \mathrm{w} \%$ clay at low and high magnification. A fine and uniform dispersion of the clay particles in a polymer matrix is seen, whereas a transcrystalline organization of iPP lamellae around the clay layers is evident; some stacked silicate layers are also observed. The for- mation of an ordered crystalline polymer/filler interface may be of prime importance and technological relevance, as it was, for instance, recognized that the nature of the interface plays a fundamental role not only for nucleation but also in the reinforcement mechanism [58, 59].
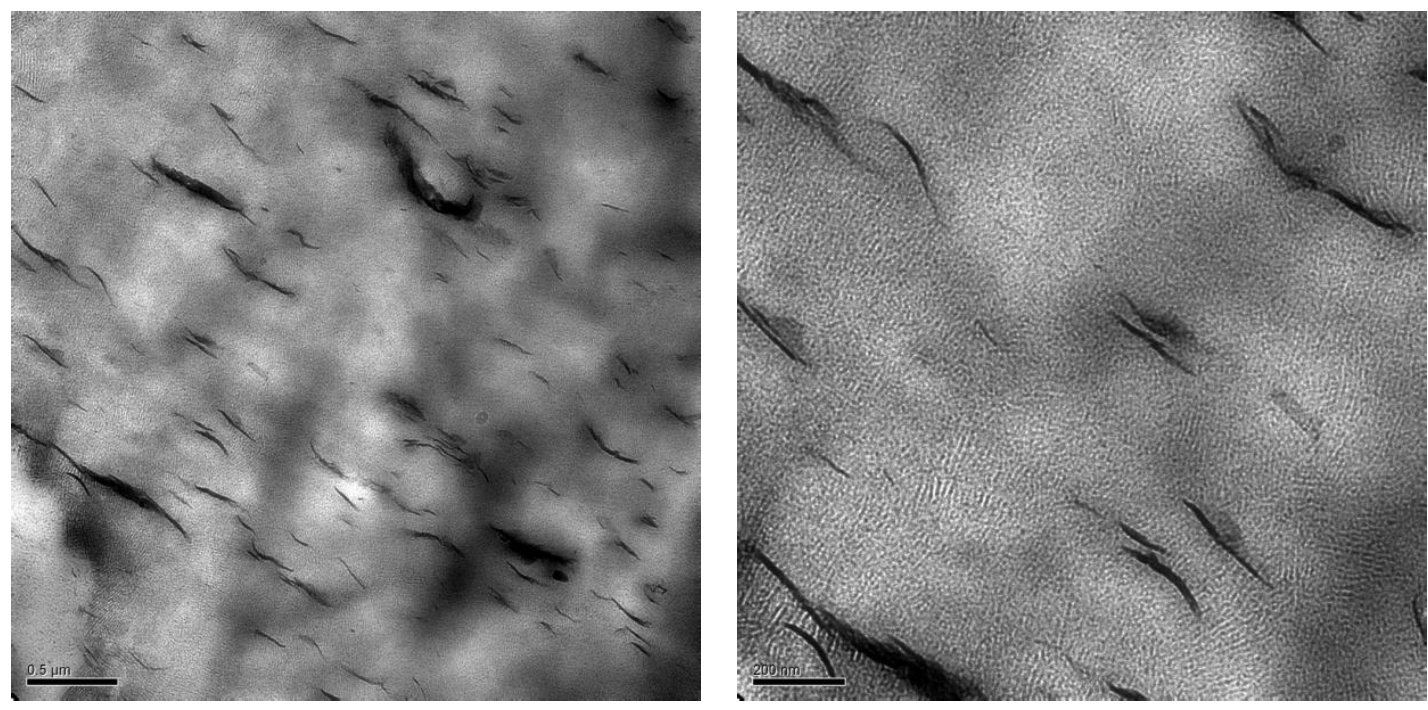

Fig 2. TEM bright-field micrograph of nanocomposite with $1 \mathrm{w} / \mathrm{w} \%$ clay at different magnifications (a, b). The dark lines are the cross sections of silicate layers and the bright area are the modified polymer matrix 


\subsection{DSC analysis}

Melting behavior. DSC melting thermograms (first run) of neat iPP and PP/clay nanocomposites, fast- and slow-cooled, are shown in Figure 3.

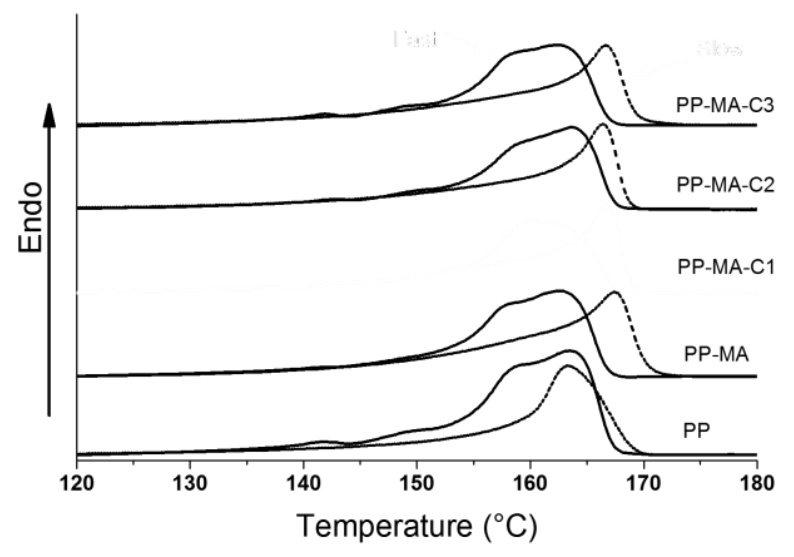

Fig 3. DSC melting traces of slow- (dotted line) and fast-cooled samples (solid line)

In Figures 4 and 5 an example of the deconvolution of DSC curve for a slow- and fast- cooled specimen into separate peaks is shown. The following Gaussian function was used for fitting the experimental data from the DSC fusion curve of the samples (eq.1):

$$
Y(T)=Y_{0}+\frac{H}{\sqrt{\frac{\pi}{2}}} \cdot e e^{\left.-2\left(\frac{\left(T-T_{c}\right)}{s}\right)\right)^{2}}
$$

where $T_{\mathrm{c}}$ is the peak position, $s$ is the full width at half-maximum, and $H$ represents the height of the peaks. The peak-fit routines were used to evaluate, by nonlinear curve fitting of experimental data, the height, the relevant features of the curves as, top center, peak height, width at half maximum and the area fraction under the peaks.

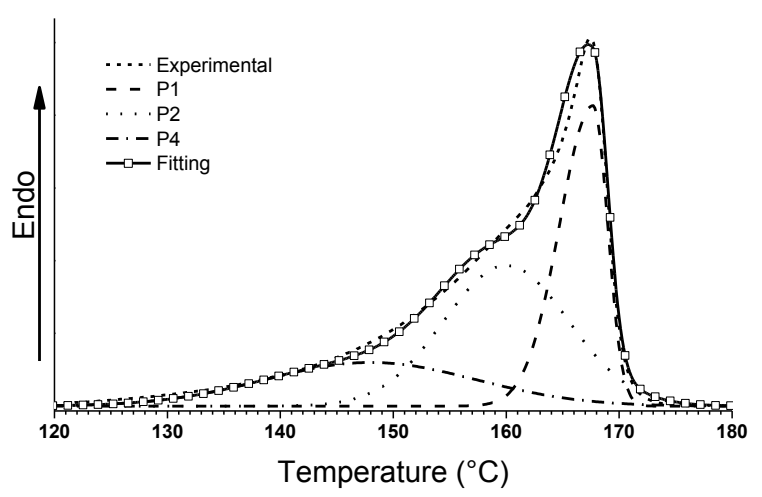

Fig 4. Example of the peak-fitting analysis of DSC melting curve for slow-cooled samples
All DSC curves exhibit multiple endotherms or, better, they are resolvable into three to four overlapping peaks. Hereafter, the peak at the higher temperature will be referred as peak-1 (P1), whilst those at lower temperatures will be called peak-2 to peak-4 (P2-P4). These peaks can be attributed to the complex melting behavior of the iPP [60-64].

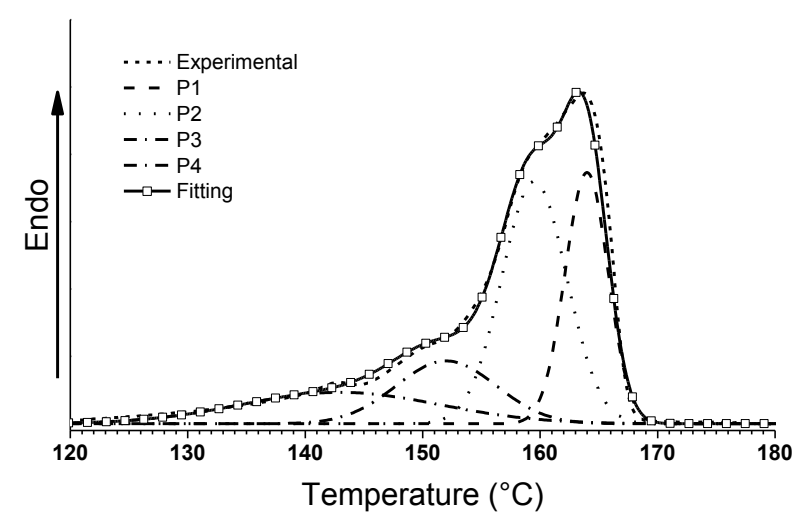

Fig 5. Example of the peak fitting analysis of DSC melting curve for fast-cooled samples

This has been ascribed to several factors, among which are the presence of different crystal forms and differences in crystallite size and perfection. However, the main reason for such multiple endotherms was attributed to the recrystallization or reorganization of some crystallized fractions.

The melting temperature, determined from deconvoluted DSC peaks of neat iPP and the nanocomposites produced by slow- and fast-cooling compression molding regime is shown in Figure 6 and Table 1.

Deconvolution of DSC curves for lower cooling rate (SC) resulted in three separate peaks for all analyzed samples. The intensity and position of the basic melting peak (P1) in neat iPP and in all nanocomposite samples crystallized at lower cooling rate did not change $\left(T_{\mathrm{ml}}=167{ }^{\circ} \mathrm{C}\right)$. The $\mathrm{P} 2$ and $\mathrm{P} 4$ in nanocomposites appeared at lower temperature as compared to neat PP. A tendency to slight decrease is seen for $\mathrm{P} 2$ with increasing clay content (from 163 to $158{ }^{\circ} \mathrm{C}$ ). In contrast, samples crystallized at high cooling rate (FC) show the presence of four melting peaks that seem less sensitive to the sample compositions. The intensity of all peaks is slightly lower, compared to the samples crystallized at lower cooling rate. As is well known, during slow crystallization processes the molecules have enough time to form more perfect crystals. In case of PP nanocomposites, the nucleating effect of the modifier (maleic anhydride), as well as that of 
the clay, obviously enhances the formation of crystals with high melting temperature. As the cooling rate increases, the crystallized fraction may consist of defective crystals, as a result of higher supercooling. In that case, the nucleating effect is less efficient, leading to the formation of high-meltingtemperature crystals. On the other hand, the defective crystals formed during cooling would undergo perfection during heating [65]. Thus, the shoulder peak, clearly seen in DSC traces of FC samples, is due to the recrystallization or reorganization of crystals formed initially during non-isothermal crystallization.

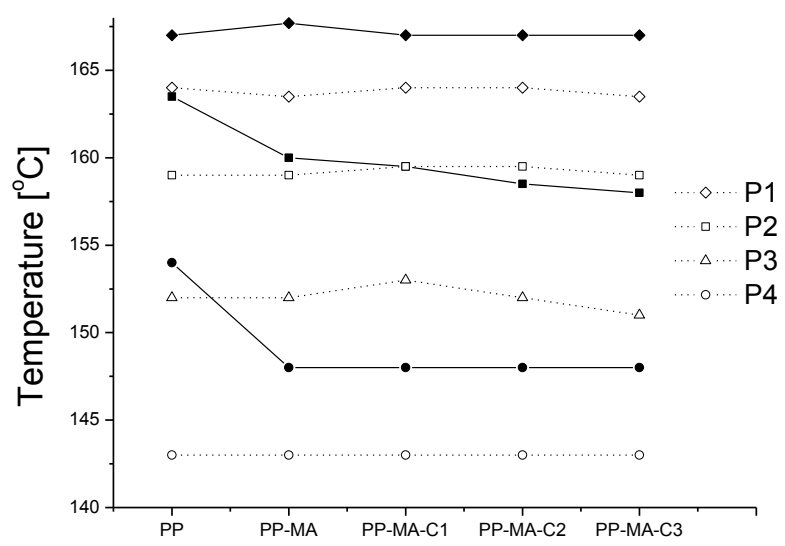

Fig 6. Melting temperature of deconvoluted peaks (filled symbols are slow-cooled, empty symbols are fast-cooled samples)

The Gibbs-Thomson relation can be used to estimate the melting temperature of crystals with finite thickness $\left(l_{\mathrm{c}}\right)$ but with infinite lateral dimensions:

$$
T_{m}=T_{m}{ }^{o}\left(1-\frac{2 \sigma_{e}}{\Delta H_{f}^{o} l_{c}}\right)
$$

where $T^{0}{ }_{\mathrm{m}}$ is the equilibrium melting temperature, $\Delta H_{\mathrm{f}}^{o}$ the equilibrium heat of fusion, and $\sigma_{\mathrm{e}}$ denotes the surface energy.

$$
\text { Assuming } T_{\mathrm{m}}^{\mathrm{o}}=186{ }^{\circ} \mathrm{C}, \Delta H_{\mathrm{f}}^{o}=8700 \mathrm{~kJ}
$$
$\mathrm{mol}^{-1}$, and $\sigma_{\mathrm{e}}=62 \mathrm{erg} \mathrm{cm}^{-2}$ for iPP [66], the lamellar thickness of the two populations of lamellae, which could originate different melting peaks, has been calculated and the obtained results are reported in Table 1.

The crystallization of the polymer matrix was altered by using two extremely different cooling rates after the molding was completed. The slowly cooled samples had slightly higher melting temperature, estimated as the maximum of the main melting peak P1. The values obtained for the melting enthalpy of slowly cooled samples indicates that the spherulites were thicker and larger. It can be seen from Table 1 that, in addition to the cooling regime, the presence of clay has also affected the morphology of nanocomposites crystallized by slow cooling, since the values determined for crystal dimensions, and especially for those of $l_{\mathrm{c}}(\mathrm{P} 2)$, decrease progressively with the amount of clay. In contrast, the presence of clay particles had no influence on crystal dimensions in fast-cooled samples. These results are in agreement with our previous findings [55].

Table 1

Meting temperature of the deconvoluted endothermic peaks. Crystal dimensions $\left(l_{c}\right)$ are calculated by eq. (2)

\begin{tabular}{lccccccccc}
\hline \hline \multirow{2}{*}{ Slow } & $\mathrm{P} 1$ & $\mathrm{P} 2$ & $\mathrm{P} 3$ & $\mathrm{P} 4$ & $l_{\mathrm{c}}(\mathrm{P} 1)$ & $\begin{array}{l}l_{\mathrm{c}}(\mathrm{P} 2) \\
/ \mathrm{nm}\end{array}$ & $\begin{array}{c}l_{\mathrm{c}} \\
(\mathrm{P} 3)\end{array}$ & $\begin{array}{c}l_{\mathrm{c}}(\mathrm{P} 4) \\
/ \mathrm{nm}\end{array}$ \\
\hline PP & 167.0 & 163.5 & - & 154.0 & 14.5 & 12.2 & - & 8.6 \\
PP-MA & 167.7 & 160.0 & - & 148.0 & 15.0 & 10.6 & - & 7.2 \\
PP-MA-C1 & 167.0 & 159.5 & - & 148.0 & 14.5 & 10.4 & - & 7.2 \\
PP-MA-C2 & 167.0 & 158.5 & - & 148.0 & 14.5 & 10.0 & - & 7.2 \\
PP-MA-C3 & 167.0 & 158.0 & - & 148.0 & 14.5 & 9.8 & - & 7.2 \\
\hline \multirow{2}{*}{ Fast } & $\mathrm{P} 1$ & $\mathrm{P} 2$ & $\mathrm{P} 3$ & $\mathrm{P} 4$ & $l_{\mathrm{c}}(\mathrm{P} 1)$ & $l_{\mathrm{c}}(\mathrm{P} 2)$ & $l_{\mathrm{c}}(\mathrm{P} 3)$ & $l_{\mathrm{c}}(\mathrm{P} 4)$ \\
& $1{ }^{\circ} \mathrm{C}$ & $/{ }^{\circ} \mathrm{C}$ & $1{ }^{\circ} \mathrm{C}$ & $\mid{ }^{\circ} \mathrm{C}$ & $/ \mathrm{nm}$ & $/ \mathrm{nm}$ & $/ \mathrm{nm}$ & $/ \mathrm{nm}$ \\
\hline PP & 164.0 & 159.0 & 152.0 & 143.0 & 12.5 & 10.2 & 8.1 & 6.4 \\
PP-MA & 163.5 & 159.0 & 152.0 & 143.0 & 12.2 & 10.2 & 8.1 & 6.4 \\
PP-MA-C1 & 164.0 & 159.5 & 153.0 & 143.0 & 12.5 & 10.4 & 8.3 & 6.4 \\
PP-MA-C2 & 164.0 & 159.5 & 152.0 & 143.0 & 12.5 & 10.4 & 8.1 & 6.4 \\
PP-MA-C3 & 163.5 & 159.0 & 151.0 & 143.0 & 12.2 & 10.2 & 7.9 & 6.4 \\
\hline \hline
\end{tabular}


Fitting analysis, besides the characterization of polymorphic forms through temperature, allows the determination of the area fraction under each overlapping curve. From these areas, the quantification of the composition of the specimens can be determined, if the molar enthalpy of the components is known. Table 2 contains the values determined for the area fraction under the peaks, ob- tained by using Gaussian functions in the deconvolution of the melting curve of each sample, recorded at $10^{\circ} \mathrm{C} \mathrm{min}^{-1}$. In the same table, the values of crystallinity, determined from the melting enthalpy of slow- and fast-cooled samples are shown, and phase fractions, previously determined by X-ray analysis [55] are also presented.

Table 2

Relative area of the deconvoluted DSC peaks (P1-P4). Crystallinity $\left(X_{c}\right)$ calculated by $X$-ray diffraction and identified polymorphic forms of iPP

\begin{tabular}{|c|c|c|c|c|c|c|c|c|c|c|}
\hline Slow & $\mathrm{P} 1$ & $\mathrm{P} 2$ & P3 & $\mathrm{P} 4$ & $\begin{array}{c}X_{\mathrm{c}} \\
1 \%, \mathrm{DSC}\end{array}$ & $\begin{array}{c}X_{\mathrm{c}} \\
1 \%, \text { Xray }\end{array}$ & $X_{\alpha} / \%$ & $X_{\beta} / \%$ & $X_{\gamma} / \%$ & $\begin{array}{l}\Delta \mathrm{W} \\
\text { /a.u. }\end{array}$ \\
\hline $\mathrm{PP}$ & $12.3 \%$ & $57.0 \%$ & $0.0 \%$ & $30.7 \%$ & $52.4 \%$ & $42.3 \%$ & $96 \%$ & $0.2 \%$ & $3.1 \%$ & 6.51 \\
\hline PP-MA & $35.0 \%$ & $42.6 \%$ & $0.0 \%$ & $22.4 \%$ & $55.4 \%$ & $44.4 \%$ & $95 \%$ & $0.3 \%$ & $4.2 \%$ & 8.68 \\
\hline PP-MA-C1 & $32.0 \%$ & $42.2 \%$ & $0.0 \%$ & $25.8 \%$ & $56.3 \%$ & $40.8 \%$ & $96 \%$ & $0.2 \%$ & $3.4 \%$ & 5.72 \\
\hline PP-MA-C2 & $31.5 \%$ & $38.7 \%$ & $0.0 \%$ & $29.8 \%$ & $55.2 \%$ & $40.8 \%$ & $96 \%$ & $0.2 \%$ & $2.8 \%$ & 5.31 \\
\hline PP-MA-C3 & $30.4 \%$ & $37.8 \%$ & $0.0 \%$ & $31.8 \%$ & $52.8 \%$ & $40.3 \%$ & $96 \%$ & $0.5 \%$ & $2.9 \%$ & 6.32 \\
\hline Fast & $\mathrm{P} 1$ & $\mathrm{P} 2$ & P3 & $\mathrm{P} 4$ & $\begin{array}{c}X_{\mathrm{c}} \\
1 \%, \mathrm{DSC}\end{array}$ & $\begin{array}{c}X_{\mathrm{c}} \\
1 \%, \text { Xray }\end{array}$ & $X_{\alpha} / \%$ & $X_{\beta} / \%$ & $X_{\gamma} / \%$ & $\begin{array}{l}\Delta \mathrm{W} \\
\text { /a.u. }\end{array}$ \\
\hline $\mathrm{PP}$ & $32.4 \%$ & $37.7 \%$ & $14.6 \%$ & $15.3 \%$ & $49.6 \%$ & $45.9 \%$ & $85 \%$ & $7.9 \%$ & - & 10.63 \\
\hline PP-MA & $25.4 \%$ & $41.8 \%$ & $16.7 \%$ & $16.1 \%$ & $47.9 \%$ & $47.2 \%$ & $86 \%$ & $6.5 \%$ & - & 10.58 \\
\hline PP-MA-C1 & $27.1 \%$ & $40.5 \%$ & $16.4 \%$ & $16.0 \%$ & $48.4 \%$ & $49.3 \%$ & $87 \%$ & $7.0 \%$ & - & 10.18 \\
\hline PP-MA-C2 & $27.6 \%$ & $40.3 \%$ & $16.1 \%$ & $16.1 \%$ & $46.5 \%$ & $46.8 \%$ & $89 \%$ & $4.8 \%$ & - & 10.14 \\
\hline PP-MA-C3 & $29.0 \%$ & $39.5 \%$ & $15.7 \%$ & $15.8 \%$ & $44.6 \%$ & $48.5 \%$ & $88 \%$ & $8.0 \%$ & - & 10.66 \\
\hline
\end{tabular}

For all the prepared nanocomposites, the slow cooling, as expected, resulted in a higher overall degree of crystallinity. Among the investigated samples, four polymorphic structural modifications have been identified. X-ray analysis has shown that the slow-cooled samples exhibited mainly alpha crystalline phase (with very low percentage of gamma phase), whereas the fast-cooled samples contained a measurable content of beta phase. According to the relative area of P1 and P2, it could be concluded that the crystallization at high temperature (slow cooling) tends to produce high-melting polymorphic forms of iPP in both neat polymer and polymer nanocomposites, whereas low temperature (fast cooling) leads to appearance of a low-melting beta phase.

From the obtained DSC endotherms, additional parameters (full-width at half height of the endotherm melting peaks, $\Delta \mathrm{W}$ ), reflecting the distribution of crystal dimensions, were determined and the results are presented in Table 2. It is evident that the values of $\Delta \mathrm{W}$ are affected by the crystallization (cooling) regime, indicating a more uniform (narrower) distribution of the crystal dimensions in slow-cooled samples. The presence of clay induced only insignificant changes in crystal di- mensions of slow-cooled samples, while it had no influence on fast-cooled ones.

\subsection{Dynamic mechanical analysis}

The viscoelastic properties of polymeric nanocomposites are key factors in the understanding of the processing-structure-property relationship in these materials [67]. The analysis of the dynamic storage modulus, loss modulus, and $\tan \delta$ is very useful for ascertaining the performance of a material under stress and temperature. It enables not only the measurement of the dynamic mechanical properties of a material, but also detection of changes in the solid structure of the polymer after addition of second phase [68]. Samples of neat iPP and PP/PP-MA/clay nanocomposites containing 1$3 \mathrm{w} / \mathrm{w} \%$ clay were subjected to dynamic mechanical tests to study viscoelastic characteristics and relaxation processes with respect to their morphological peculiarities.

\subsection{Storage modulus}

The storage modulus $(E ')$ is the measure of stiffness, describing the range where the elastic 
property is higher. The higher the range, the higher will be the stiffness and load-bearing capability of a material $[69,70]$. Storage modulus of neat PP and nanocomposites, obtained during slow and fast cooling regimes, in a temperature range of -50 to $+150{ }^{\circ} \mathrm{C}$, are shown in Figure $7(\mathrm{a}-\mathrm{c})$.

As can be seen from Figure 7 and Table 3, the effect of nanoclay on the mechanical properties of PP-nanocomposites is evident. Moreover, the
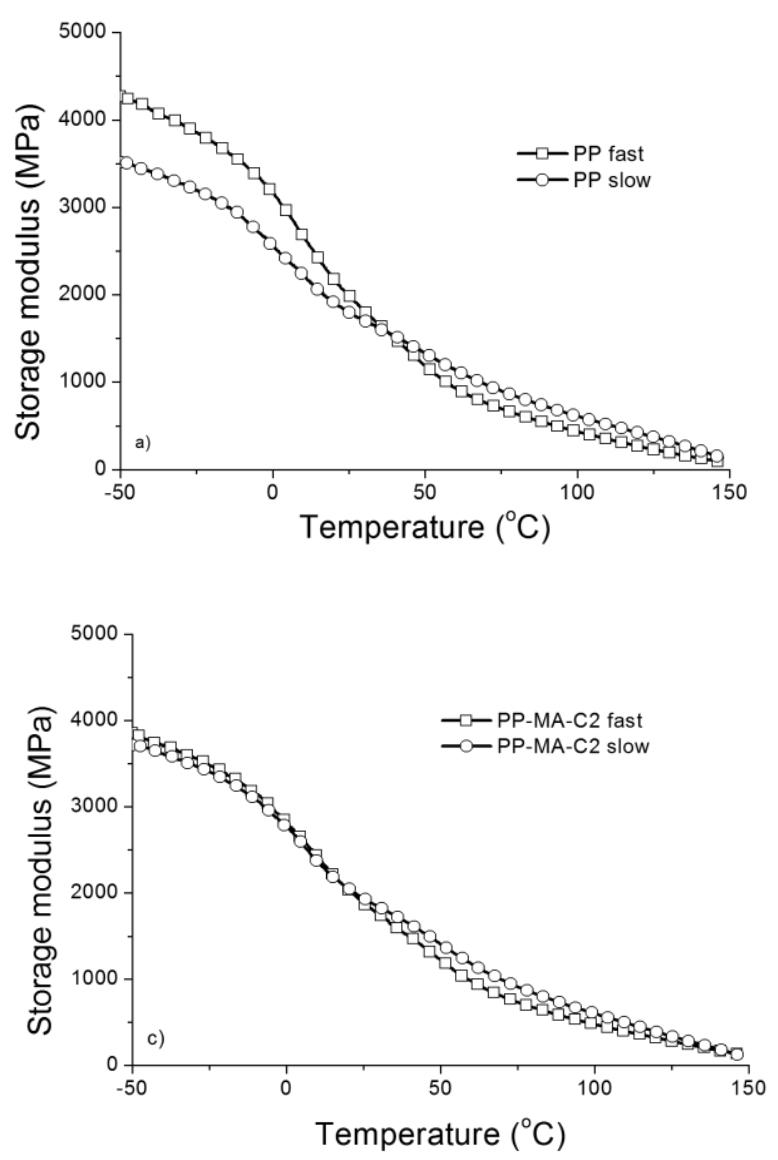

presence of clay induced significant change in overall viscoelastic behavior of the polymer (see Fig. 7a). Different behaviors of nanocomposites produced via slow- or fast-cooling compression molding cycles can be explained in terms of the reported morphological peculiarities. Based on previous results, the following mechanism of the microstructure formation during different processing condition could be proposed (Fig. 8).
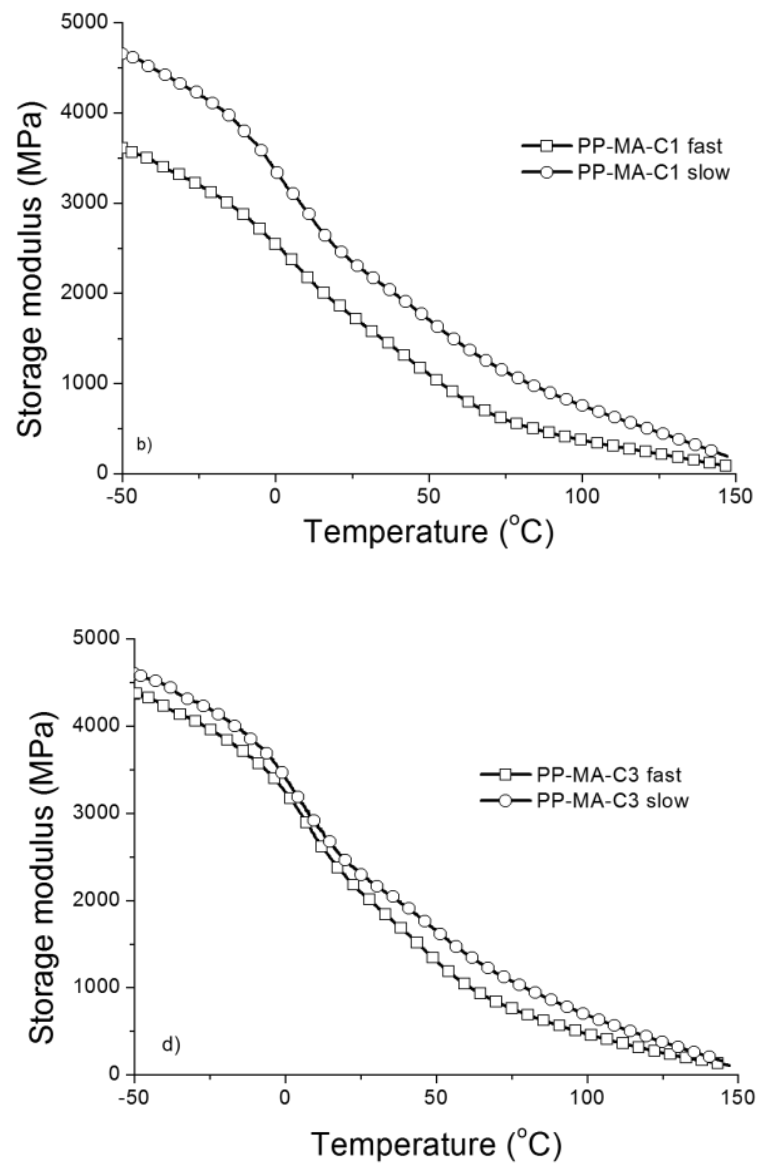

Fig 7. Temperature dependence of storage modulus neat PP and nanocomposite with $1-3 \mathrm{w} / \mathrm{w} \%$ clay

At low temperatures, the interconnections between the fine-grained crystals (a kind of selfreinforcing structure) present in the morphology of a fast-cooled neat PP sample have resulted in a high level of elastic modulus (see Fig. 7a). In contrast, the coarse morphology of the slow-cooled PP sample is obviously less resistant to mechanical deformation. At higher temperatures, the mechanical deformation produced a flow of the polymer crystals in the amorphous phase, and hence, the higher dimensions of the crystals in the slow-cooled sample produced higher resistance compared to the fine morphology of the fast-cooled sample.

The behavior of nanocomposites is quite different from that of the neat polymer. In general, the values of storage modulus are higher for the nanocomposites obtained via slow cooling. This might be attributed to the better reinforcing effect, i.e. to stronger interactions created between the clay galleries and the matrix during the slow-cooling process (lasting approximately $3 \mathrm{~h}$ ), allowing, in turn, greater degree of stress transfer at the interface. The formation of transcrystalline interfaces in the vicinity of clay layers, as detected by TEM (Fig. $2 b$ ), certainly affects the strength of interfacial regions. Furthermore, partial exfoliation of the clay galleries in the PP matrix (detected for all nanocomposites, and especially pronounced at $1 \mathrm{w} / \mathrm{w} \%$ loading of clay) has additionally restricted segmental motion at the interface [69]. 
Table 3

Dynamic storage modulus $E^{\prime}$ of neat $P P$ and nanocomposites, in the temperature range from $-50^{\circ} \mathrm{C}$ to $+100^{\circ} \mathrm{C}$ for slow and fast cooled samples

\begin{tabular}{lcccccccc}
\hline \hline \multirow{2}{*}{ Sample } & \multicolumn{8}{c}{ Dynamic storage modulus / MPa } \\
\cline { 2 - 10 } & \multicolumn{2}{c}{$-50{ }^{\circ} \mathrm{C}$} & \multicolumn{2}{c}{$0{ }^{\circ} \mathrm{C}$} & \multicolumn{2}{c}{$50{ }^{\circ} \mathrm{C}$} & \multicolumn{2}{c}{$100{ }^{\circ} \mathrm{C}$} \\
\hline & $\mathrm{FC}$ & $\mathrm{SC}$ & $\mathrm{FC}$ & $\mathrm{SC}$ & $\mathrm{FC}$ & $\mathrm{SC}$ & $\mathrm{FC}$ & $\mathrm{SC}$ \\
PP & 4264 & 3517 & 3168 & 2560 & 1187 & 1329 & 434 & 610 \\
PP-MA-C1 & 3608 & 4654 & 2544 & 3363 & 1104 & 1709 & 372 & 758 \\
PP-MA-C2 & 3854 & 3718 & 2811 & 2766 & 1220 & 1410 & 476 & 601 \\
PP-MA-C3 & 4363 & 4600 & 3247 & 3400 & 1302 & 1654 & 466 & 684 \\
\hline \hline
\end{tabular}

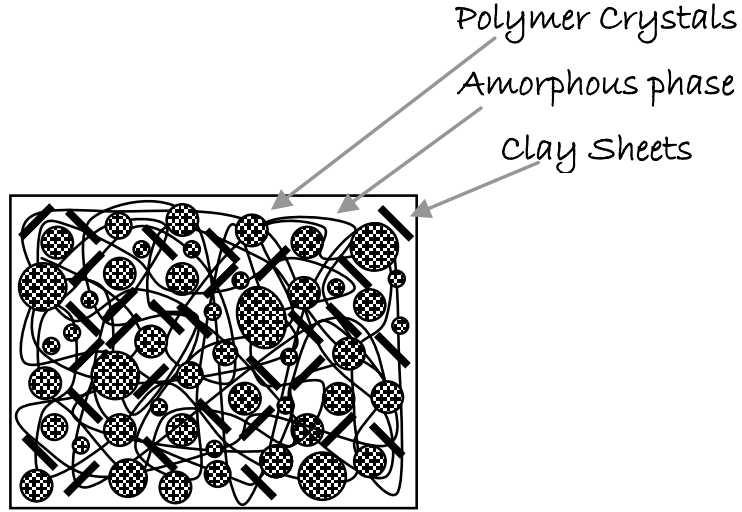

Fast Cooling

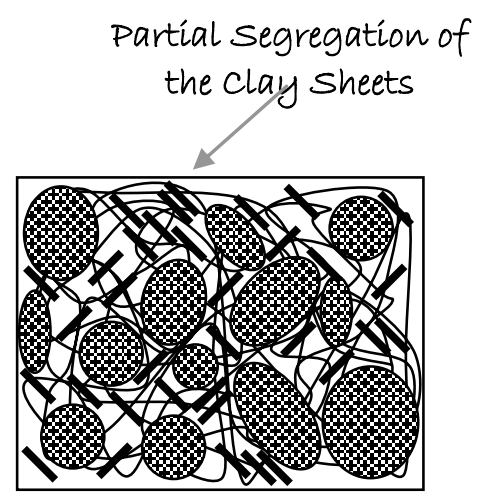

Slow Cooling

Fig 8. Schematic representation of the microstructure formed during compression molding cycle

The effect of cooling rate applied in the compression molding cycle on dynamic storage modulus $E^{\prime}$ of neat $\mathrm{PP}$ and nanocomposites at $50{ }^{\circ} \mathrm{C}$ is shown in Table 3. Evidently, at $T>T_{\mathrm{g}}$, nanocomposites obtained by slow cooling exhibited better mechanical response as compared to the fast-cooled samples. The value of dynamic modulus $E$ ' of slowcooled samples increased by $\sim 55 \%$ with addition of only $1 \mathrm{w} / \mathrm{w} \%$ clay. This enhancement of dynamic storage modulus $E$ ' is ascribed to the better nanoscale dispersion of the layered clays (as shown by WAXD), which resulted in higher aspect ratio of the reinforcing clay particles.

The obtained results for thermo-mechanical behavior of PP/clay nanocomposites are in agreement with those reported earlier by Sharma et al. [70], Lei et al. [71] and Lai et al. [72]. The extent in increase of storage modulus is found to be related to the type of nanoclay, clay content, compatibilizer and processing parameters [67]. The addition of $1 \mathrm{w} / \mathrm{w} \%$ organo-modified clay, exfoliated in a PP matrix by application of latex technology, particularly at temperatures higher than $T_{\mathrm{g}}$, caused the storage modulus to increase by approximately $30 \%$ [73]. The same extent of increase of storage modulus in PP/clay composites at low clay loading has also been observed by Misra et al. [74], Hambir et al. [75] and Venkatesh et al. [67], whereas Sharma and Nayak [70] reported only 10$17 \%$ increase. The increase in storage modulus indicates the mechanical reinforcing effect of nanoclay in the composites. However, none of these results presented in the literature are correlated with the morphological characteristics of the matrix polymer used.

\subsection{Dynamic loss modulus}

The loss modulus denotes the energy dissipated by the system in the form of heat, and measures the viscous response of the polymer material [67]. The loss modulus curves of neat PP and the nanocomposites are illustrated in Figure 9. In $\mathrm{PP}$ and nanocomposites over the entire temperature region (from -50 to $+150{ }^{\circ} \mathrm{C}$ ), two main relaxation processes are observed, which were related to $\beta$ - 
and $\alpha$-relaxations, respectively. The dominant relaxation, appearing around $10{ }^{\circ} \mathrm{C}$, is related to the glass-rubber transition ( $\beta$-relaxation) of the amorphous phase of PP. The weak peak at high temperatures corresponds to the $\alpha$-relaxation. There are different interpretations of the nature of $\alpha$ relaxation in PP. It may be caused by molecular mobility of the polymer chains on the lamellar surface or by relaxation of the intracrystalline amorphous chains of PP [67].

The effect of morphology of the polymer matrix is also clearly seen from the curves for $E^{\prime \prime}$. The curves for the slow-cooled nanocomposites are all located above that for neat PP, which is not the case with those cooled fast. In contrast, although all samples displayed similar relaxation peaks, the presence of clay in fast-cooled nanocomposites led to a decrease in the $E^{\prime \prime}$ of the PP matrix.

The mechanism of energy dissipation in nanocomposites of different morphological features is quite different, due to the crystalline structure and interactions at the interface. This is best illustrated at low clay content $(1 \mathrm{w} / \mathrm{w} \%)$ with dominant exfoliated structure in slow-cooled nanocomposites (as revealed by WAXD), which in turn leads to a significant improvement in the modulus.
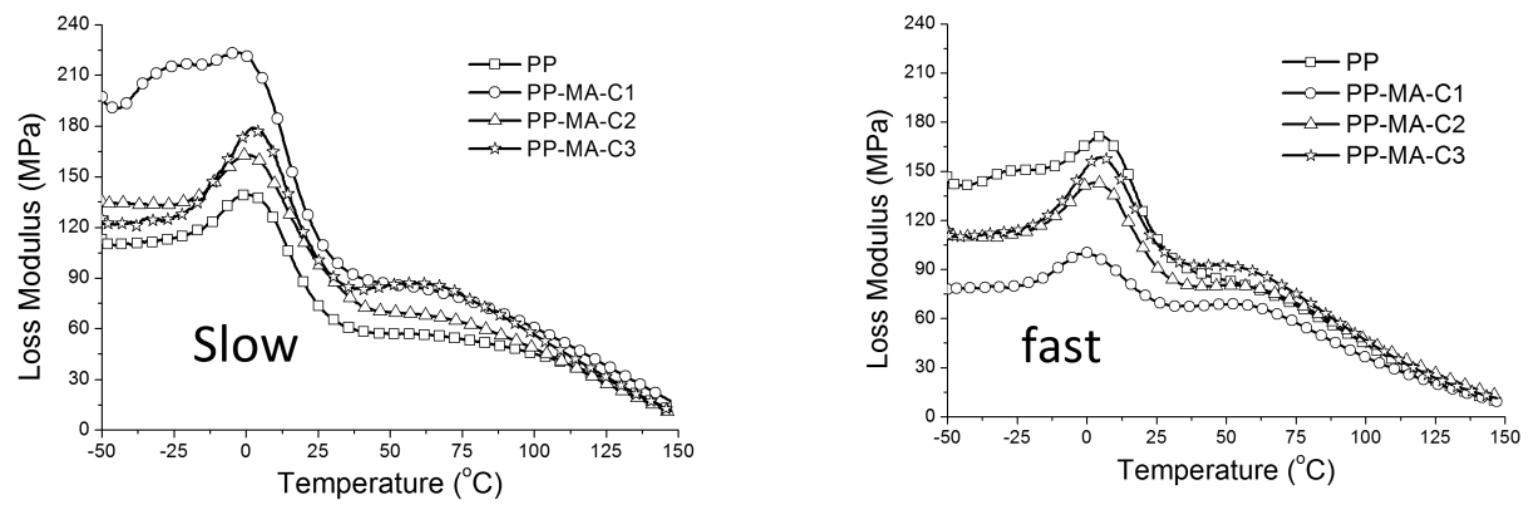

Fig 9. Temperature dependence of loss modulus for: a) slow-cooled and b) fast-cooled neat PP and nanocomposites with $1-3 \mathrm{w} / \mathrm{w} \%$ clay

Venkantesh et al. [67], Samal et al. [76] and Yang et al. [77] have reported that incorporation of nanoclays leads to an enhancement in the magnitude $E$ " of the PP matrix. It was also shown [77] that the addition of nanoclay did not affect the loss modulus temperature (as the peak is around $4{ }^{\circ} \mathrm{C}$ ), which is mainly concerned with the molecular motion of the crystalline region of PP. This suggests that the nanoclay did not affect relaxation behavior of PP.

From DMTA measurements, the $T_{\mathrm{g}}$ of nanocomposites was determined (Fig. 10), and it was found that the values are insignificantly shifted towards higher temperatures compared to the matrix polymer, apparently due to the effect of the clay particles on the mobility of polymer chains [78].
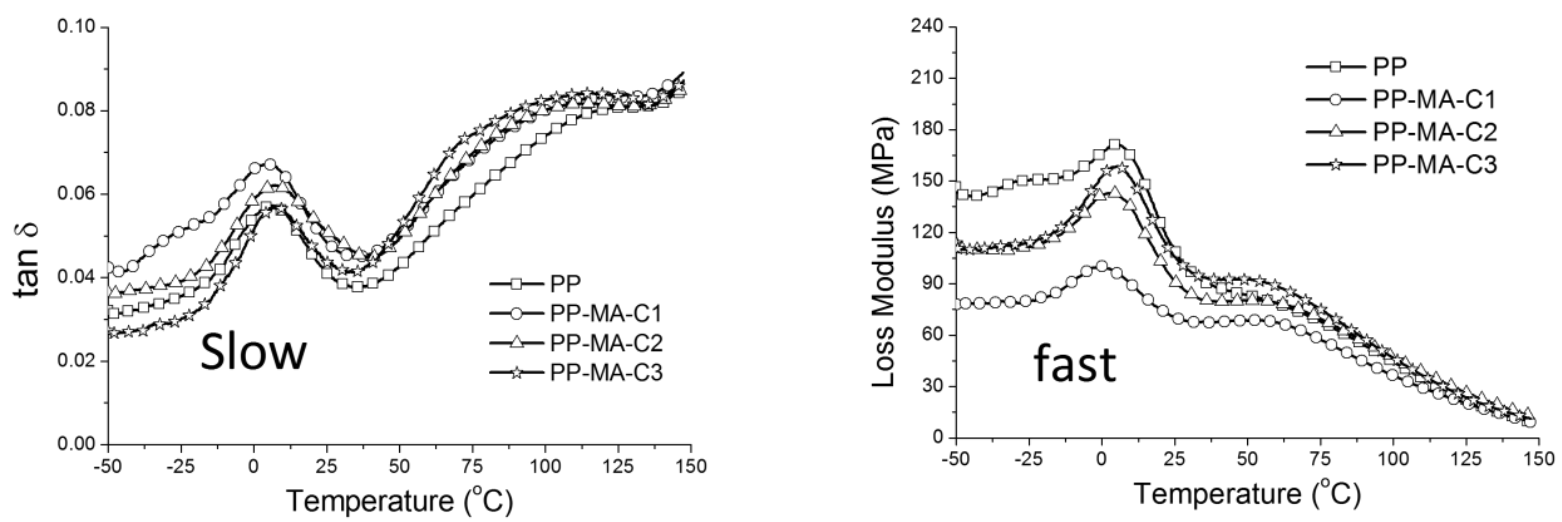

Fig 10. Temperature dependence of $\tan \delta$ for:

a) slow-cooled and b) fast-cooled neat PP and nanocomposites with $1-3 \mathrm{w} / \mathrm{w} \%$ clay 
It is well known that the $T_{\mathrm{g}}$ of a polymer depends on the mobility of the chain segment of the macromolecules. If the molecular chain is restricted, motion or relaxation of the chain segment becomes difficult at the original glass transition temperature and becomes possible only at higher temperatures. Similar behavior has also been reported by other researchers [40, 76, 79]. However, Samal et al. [76] reported a decrease in $T_{\mathrm{g}}$ for PP nanocomposites, indicating that the amorphous molecules become mobile at lower temperature as compared to virgin $\mathrm{PP}$, which in this case was assigned to the existence of low-molecular-weight intercalants in nanoclays.

\section{CONCLUSION}

A comparative analysis of the effect of matrix morphology, originated as a result of two extremely different crystallization regimes applied in the phase of compression molding, on the melting behavior and thermo-mechanical properties of $\mathrm{PP} /$ clay nanocomposites has been presented. A nonlinear curve-fitting of DSC melting curves has shown that the recrystallization/reorganization of the initially formed crystals during nonisothermal crystallization took place in fast-cooled nanocomposite samples. It was also shown that the slowcooled samples exhibited mainly alpha crystalline phase, whereas the fast-cooled samples contained a measurable content of beta phase. The presence of clay particles had no influence on crystal dimensions in fast-cooled nanocomposite samples, and on the contrary, in addition to the cooling rate, their presence had affected the polymer morphology in slow-cooled samples. The crystal dimensions decreased progressively with the amount of clay added. DMA results showed an increase in storage modulus of the PP matrix in nanocomposites, indicating an increase in the stiffness of the matrix polymer induced by the presence of clay platelets. In the investigated temperature range (from -50 to $+150{ }^{\circ} \mathrm{C}$ ), the slow-cooled nanocomposite samples exhibited higher values of storage modulus, indicating the better reinforcing effect of layered silicate, and enhanced interfacial interactions created during prolonged time of crystallization. Thus, the value of dynamic storage modulus increased by $\sim 55 \%$ with addition of only $1 \mathrm{w} / \mathrm{w} \%$ of clay; the effect being ascribed to partial exfoliation of the clay galleries in the PP matrix and the formation of transcrystalline interfaces in the vicinity of clay layers, detected by TEM.

\section{REFERENCES}

[1] V. Kumar, A. Singh, Polypropylene clay nanocomposites, Rev. Chem. Eng., 29 (6), 439-448 (2013).

[2] M. Alexandre, P. Dubois, Polymer-layered silicate nanocomposites: Preparation, properties and uses of a new class of materials, Mater. Sci. Eng: Review, 28, 163 (2000). DOI: 10.1016/S0927-796X(00)00012-7

[3] K. Prashantha, J. Soulestin, M. F. Lacrampe, P. Krawczak, Present status and key challenges of carbon nanotubes reinforced polyolefins: A review on nanocomposites manufacturing and performance issues. Polym. Polym. Compos., 17, 205-245 (2009).

[4] Z. Shi, X. Gao, D. Song, Y. Zhou, D. Yan, Preparation of poly ( $\varepsilon$-caprolactone) grafted titanate nanotubes, Polymer, 48, 7516-7522 (2007).

DOI: https://doi.org/10.1016/j.polymer.2007.10.037

[5] A. Sorrentino, R. Pantani, V. Brucato, Injection molding of syndiotactic polystyrene/clay nanocomposites, Polym. Eng. Sci., 46 (12), 1768-1777 (2006). DOI: $10.1002 /$ pen. 20650

[6] S. P. Bao, S. C. Tjong, Mechanical behaviors of polypropylene/carbon nanotube nanocomposites: The effects of loading rate and temperature, Mater. Sci. Eng, A 485: 508-516 (2008).

DOI: https://doi.org/10.1016/j.msea.2007.08.050

[7] K. Prashantha, J. Soulestin, M. F. Lacrampe, P. Krawczak, G. Dupin, M. Claes, Masterbatch-based multiwalled carbon nanotube filled polypropylene nanocomposites: Assessment of rheological and mechanical properties, Compos. Sci. Technol., 69, 1756-1763 (2009). DOI: https://doi.org/10.1016/j.compscitech.2008.10.005

[8] K. Prashantha, J. Soulestin, M. F. Lacrampe, P. Krawczak, G. Dupin, M. Claes, Taguchi analysis of shrinkage and warpage of injection-moulded polypropylene/multiwall carbon nanotubes nanocomposites, Express Polym. Lett., 3, 630-638 (2009). DOI: 10.3144/expresspolymlett.2009.79

[9] H. Zhang, Z. Zhang, Impact behaviour of polypropylene filled with multi-walled carbon nanotubes, Eur. Polym J., 43, 3197-3207 (2007).

DOI: https://doi.org/10.1016/j.eurpolymj.2007.05.010

[10] M. A. López Manchado, L. Valentini, J. Biagiotti, J. M. Kenny, Thermal and mechanical properties of singlewalled carbon nanotubes-polypropylene composites prepared by melt processing, Carbon, 43, 1499-1505 (2005). DOI: https://doi.org/10.1016/j.carbon.2005.01.031

[11] J. Hári, Z. Dominkovics, E. Fekete, B. Pukánszky, Kinetics of structure formation in PP/layered silicate nanocomposites, Express Polym. Lett., 3, 692-702 (2009), 10.3144/expresspolymlett.2009.87.

[12] A. C. Chinellato, S. E. Vidotti, G-H. Hu, L. A. Pessan, Compatibilizing effect of acrylic acid modified polypropylene on the morphology and permeability properties of polypropylene/organoclay nanocomposites, Compos. Sci. Technol., 70, 458-465 (2010).

DOI: https://doi.org/10.1016/j.compscitech.2009.11.020

[13] L. Betega de Paiva, A. R. Morales, T. Ribeiro Guimarães, Structural and optical properties of polypropylene-montmorillonite nanocomposites, Mater. Sci. Eng., A 447, 261-265 (2007).

DOI: https://doi.org/10.1016/j.msea.2006.10.066 
[14] H. U. Zaman, P. D. Hun, R. A. Khan, K. B. Yoon, Polypropylene/clay nanocomposites: Effect of compatibilizers on the morphology, mechanical properties and crystallinity behaviors, J. Thermoplastic Compos. Mater., 27 (3), 338-349 (2014).

DOI: https://doi.org/10.1177/0892705712446017

[15] L. Raka, A. Sorrentino, G. Bogoeva-Gaceva, Isothermal crystallization kinetics of polypropylene latex-based nanocomposites with organo-modified clay, J. Polym. Sci. Part B: Polym. Phys., 48 (17), 1927-1938 (2010). DOI: $10.1002 /$ polb.22069.

[16] G. Z. Papageorgiou, D. S. Achilias, D. N. Bikiaris, G. P. Karayannidis Crystallization kinetics and nucleation activity of filler in polypropylene/surface-treated $\mathrm{SiO}_{2}$ nanocomposites, Thermochimica Acta, 427, 117-128 (2005). DOI: https://doi.org/10.1016/j.tca.2004.09.001

[17] Y. A. Mubarak, F. O. Abbadi, A. H. Tobgy, Effect of iron oxide nanoparticles on the morphological properties of isotactic polypropylene, J. Appl. Polym. Sci., 115, 3423-3433 (2010). DOI:10.1002/app.31374.

[18] V. Causin, C. Marega, A. Marigo, G. Ferrara, A. Ferraro, Morphological and structural characterization of polypropylene/conductive graphite nanocomposites. Eur. Polym. J., 42, 3153-3161 (2006).

DOI: https://doi.org/10.1016/j.eurpolymj.2006.08.017

[19] K. Yang, Q. Yang, G. Li, Y. Sun, D. Feng, Morphology and mechanical properties of polypropylene/calcium carbonate nanocomposites, Mater. Lett., 60, 805-809 (2006). DOI: https://doi.org/10.1016/j.matlet.2005.10.020

[20] B. Hoffmann, C. Dietrich, R. Thomann, C. Friedrich, R. Mulhaupt, Morphology and rheology of polystyrene nanocomposites based upon organoclay. Macro. Rapid. Commun., 21, 57-61 (2000). DOI: 10.1002/(SICI)15213927(20000101)21:1<57::AID-MARC57>3.0.CO;2-E.

[21] Y. T. Lim, O. O. Park, Phase morphology and rheological behavior of polymer/layered silicate nanocomposites, Rheol Acta, 40, 220-229 (2001).

DOI: https://doi.org/10.1007/s003970000

[22] R. Krishnamoorti, R. A. Vaia, E. P. Giannelis, Structure and dynamics of polymer-layered silicate nanocomposites, Chem. Mater., 8, 1728-1734 (1996). DOI: $10.1021 / \mathrm{cm} 960127 \mathrm{~g}$.

[23] R. A. Vaia, E. P. Giannelis, Polymer melt intercalation in organically-modified layered silicates: Model predictions and experiment, Macromolecules, 30, 8000-8009 (1997). DOI: $10.1021 / \mathrm{ma} 9603488$

[24] V. Mittal, Polymer Layered Silicate Nanocomposites: A Review, Materials, 2, 992-1057 (2009). DOI: $10.3390 / \mathrm{ma} 2030992$

[25] A. T. Mark, P. O. James, Ubiquity of soft glassy dynamics in polypropylene/clay nanocomposites, Polymer 48, 1083-1095 (2007). DOI: https://doi.org/10.1016/j.polymer.2006.12.029

[26] K. Wang, S. Liang, P. Zhao, C. Qu, H. Tan, R. Du, Q. Zhang, F. Qu, Correlation of rheology-orientationtensile property of isotactic polypropylene organoclay nanocomposites, Acta Mater., 55, 3143-3154 (2007), DOI: https://doi.org/10.1016/j.actamat.2007.01.020
[27] A. D. Drozdov, J. Christiansen, Cyclic viscoelastoplasticity of polypropylene/nano clay composites, Mech. Time-Depend. Mater., 16, 397-425 (2012). DOI: $10.1007 / \mathrm{s} 11043-012-9169-\mathrm{x}$

[28] M. A. Perez, B. L. Rivas, S. M. Rodriguez, A. Maldonado, C. Venegas, Polypropylene/clay nanocomposites: Synthesis and characterization, J. Chin. Chem. Soc., 55, 440-444 (2010). DOI: $10.4067 /$ S0717-97072010000400006.

[29] N. Hasegawa, H. Okamoto, M. Kato, A. Usuki, Preparation and mechanical properties of polypropylene/clay hybrids based on modified polypropylene and organophilic clay, J. Appl. Polym. Sci., 78, 1918-1922 (2000), DOI: $10.1002 / 1097-4628(20001209) 78: 11<1918:: A I D-$ APP100>3.0.CO;2-H.

[30] P. Nam, P. Maiti, M. Okamoto, T. Kotaka, N. Hasegawa, A. Usuki, A hierarchical structure and properties of intercalated polypropylene/clay nanocomposites, Polymer, 42, 9633-9640 (2001). DOI: https://doi.org/10.1016/S0032-3861(01)00512-2

[31] X. Liu, Q. Whu, PP/clay nanocomposites prepared by grafting-melt intercalation, Polymer, 42, 10013-10019 (2001). DOI: https://doi.org/10.1016/S0032-3861(01)00561-4

[32] Y. Wang, F. B. Chen, K. C. Wu, Twin-screw extrusion compounding of polypropylene/organoclay nanocomposites modified by maleated polypropylenes. J. Appl. Polym. Sci., 93, 100-112 (2004). DOI: 10.1002/app.20407.

[33] G. Gorrasi, M. Tortora, V. Vittoria, D. Kaempfer, R. Mulhaupt, Transport properties of organic vapors in nanocomposites of organophilic layered silicate and syndiotactic polypropylene, Polymer, 44, 3679-3685 (2003). DOI: https://doi.org/10.1016/S0032-3861(03)00284-2

[34] S. C. Tjong, Y. Z. Meng, A. S. Hay, Novel preparation and properties of polypropylene-vermiculite nanocomposites. Chem. Mater., 14, 44-51 (2002). DOI: $10.1021 / \mathrm{cm} 010061 \mathrm{~b}$.

[35] J. Ma, Z. Qi, Y. Hu, Synthesis and characterization of polypropylene/clay nanocomposites, J. Appl. Polym. Sci., 8, 3611-3617 (2001). DOI: 10.1002/app.2223

[36] J. H. Kim, C. M. Koo, Y. S. Choi, K. H. Wang, I. J. Chung, Preparation and characterization of polypropylene/layered silicate using an antioxidant, Polymer, 45 7719-7727 (2004).

DOI: https://doi.org/10.1016/j.polymer.2004.09.016

[37] F. C. Chiu, S. M. Lai, J. W. Chen, P. H. Chu, Combined effects of clay modifications and compatibilizers on the formation and physical properties of melt-mixed polypropylene/clay nanocomposites, J. Polym. Sci. Part. B: Polym. Phys., 42, 4139-4150 (2004). DOI: $10.1002 /$ polb.20271

[38] Y. Q. Zhang, J. H. Lee, H. J. Jang, C. W. Nah, Preparing $\mathrm{PP} /$ clay nanocomposites using a swelling agent, Composites Part B, 35, 133-138 (2004). DOI: https://doi.org/10.1016/S1359-8368(03)00068-4

[39] C. Ding, D. Jia, H. He, B. Guo, H. Hong, How organomontmorillonite truly affects the structure and properties of polypropylene, Polym. Test., 24, 94-100 (2005). DOI: https://doi.org/10.1016/j.polymertesting.2004.06.005 
[40] J. I. Velasco, M. Ardanuy, V. Realinho, M. Antunes, A. I. Fernandez, J. I. Gonzalez-Pena, M. A. RodriguezPerez, J. A. de Saja, Polypropylene/clay nanocomposites: combined effects of clay treatment and compatibilizer polymers on the structure and properties, J. Appl. Polym. Sci., 102, 1213-1223 (2006). DOI: 10.1002/app.24419

[41] A. Costantino, V. Pettarin, J. C. Viana, A. J. Pontes, A. S. Pouzada, P. Frontini, Microstructure of PP/clay nanocomposites produced by shear induced injection molding, Procedia Mater. Sci., 1, 34-43 (2012). DOI: https://doi.org/10.1016/j.mspro.2012.06.005

[42] S. Arunachalam, M. G. Battisti, C. T. Vijayakumar, W. Freisenbichler, An investigation of mechanical and thermal properties of polymer clay nanocomposites containing different nanoclays, Macromol. Mater. Eng., 300 (10), 966-976 (2015). DOI: 10.1002/mame.201500107

[43] D. D. J. Rousseaux, M. Sclavons, P. Godard, J. Marchand-Brynaert, Polypropylene/clay nanocomposites: An innovative one-pot process, Polym. Compos. 36 (4), 644-650 (2015). DOI: 10.1002/pc.22982

[44] D. D. J. Rousseaux, I. N. Sallem, A. C. Baudouin, P. Godard, J. Marchand-Brynaert, M. Sclavons, Waterassisted extrusion of polypropylene/clay nanocomposites: a comprehensive study, Polymer, 52, 443-451 (2010).

DOI: https://doi.org/10.1016/j.polymer.2010.11.027

[45] S. Lee, J. Yoo, J. W. Lee, Water-assisted extrusion of polypropylene/clay nanocomposites in high shear condition, J. Industr. Eng. Chem., 31, 317-322 (2015). DOI: https://doi.org/10.1016/j.jiec.2015.07.004

[46] R. Klitkou, E. A. Jensen, J. C. Christiansen, Effect of multiple extrusions on the impact properties of polypropylene/clay nanocomposites, J. Appl. Polym. Sci., 126 (2), 620-630 (2012). DOI: 10.1002/app.36639

[47] J. A. M. Ferreira, P. N. B. Reis, J. D. M. Costa, B. C. H. Richardson, M. O. W. Richardson, A study of the mechanical properties on polypropylene enhanced by surface treated nanoclays, Compos. Part B, 42, 1366-1372 (2011). DOI: https://doi.org/10.1016/j.compositesb.2011.05.038

[48] N. Soleimani, S. M. Khalili, R. E. Farsani, Z. H. Naseb, Mechanical properties of nanoclay reinforced polypropylene composites at cryogenic temperature, J. Reinf. Plast. Compos., 31, 967-976 (2012).

DOI: https://doi.org/10.1177/0731684412450349

[49] A. G. Mahmoud, Rheological characterization of melt compounded polypropylene/clay nanocompositers, Compos. Part B, 42, 1044-1047 (2011).

DOI: https://doi.org/10.1016/j.compositesb.2011.03.025

[50] R. M. Boumbimba, K. Wang, N. Bahlouli, S. Ahzi, Y. Remond, F. Addiego, Experimental investigation and micromechanical modeling of high strain rate compressive yield stress of a melt mixing polypropylene organoclay nanocomposites, Mech. Mater., 52, 58-68 (2012). DOI: https://doi.org/10.1016/j.mechmat.2012.04.006

[51] M. Canetti, S. T. Scafati, A. Cacciamani, F. Bertini, Influence of hydrogenated oligo(cyclopentadiene) on the structure and the thermal degradation of polypropylene-based nanocomposites, Polym. Degrad. Stab., 97, 81-87 (2012). DOI: https://doi.org/10.1016/j.polymdegradstab.2011.10.007
[52] A. Fina, F. Cuttica, G. Camino, Ignition of polypropylene/montmorillonite nanocomposites, Polym. Degrad. Stab., 97, 2619-2626 (2012).

DOI: https://doi.org/10.1016/j.polymdegradstab.2012.07.017

[53] V. Pettarin, F. Brun, J. C. Viana, A. S. Pouzada, P. M. Frontini, Toughness distribution in complex PP/nanoclay injected mouldings, Compos. Sci. Technol., 74, 28-36 (2013). DOI: https://doi.org/10.1016/j.compscitech.2012.09.015

[54] K. Kalaitzdou, H. Fukushima, P. Askeland, L. T. Drzal, The nucleating effect of exfoliated graphite nanoplatelets and their influence on the crystal structure and electrical conductivity of polypropylene nanocomposites, $J$. Mater. Sci., 43, 2895-2907 (2008). DOI: $10.1007 / \mathrm{s} 10853-007-1876-3$

[55] G. Bogoeva-Gaceva, L. Raka, Gj. Petruševski, Photooxidative behavior of isotactic-polypropylene/clay nanocomposites produced via single-step extrusion method at different cooling conditions. In: Polypropylene: Synthesis, Applications and Environmental Concerns, L. Paulino Silva, E. Fernandes Barbosa (Eds.), Nova Publisher, NY, 2013, Chapter 14, pp. 321-342.

[56] G. Bogoeva-Gaceva, Lj. Raka, B. Dimzoski, Thermal stability of polypropylene/organo-clay nanocomposites produced in a single-step mixing procedure, Adv. Compos. Lett., 17, 161-164 (2008).

[57] L. Raka, G. Bogoeva-Gaceva, J. Loos, Characterization of polypropylene/layered silicate nanocomposites prepared by single-step method, J. Therm. Anal. Calorim. 100 (2), 629-639 (2010).

DOI: https://doi.org/10.1007/s10973-009-0545-y

[58] J. Zheng, X. Lu, C. L. Toh, T. H. Zheng, C. He, Effects of clay on polymorphism of polypropylene in polypropylene/clay nanocomposites, J. Polym. Sci. Part B Polym. Phys., 42, 1810-1816 (2004).

DOI: $10.1002 /$ polb.20043

[59] H. E. Miltner, N. Grossiord, K. Lu, J. Loos, C. E. Koning, B. Van Mele, Isotactic polypropylene/carbon nanotube composites prepared by latex technology. Thermal analysis of carbon nanotube-induced nucleation, Macromolecules, 41, 5753-5762 (2008). DOI: $10.1021 / \mathrm{ma} 800643 \mathrm{j}$

[60] K. D. Pae, $\gamma-\alpha$ Solid-solid transition in isotactic polypropylene, J. Polym. Sci., A-2, Polym. Phys., 6, 657-663 (1968). DOI: 10.1002/pol.1968.160060401

[61] J. L. Kardos, A. W. Christiansen, E. Baer, Structure of pressure-crystallized polypropylene, J. Polym Sci. Part B: Polym Phys., 4 (5), 777-788 (1966). DOI: https://doi.org/10.1002/pol.1966.160040509

[62] R. J. Samuels, Quantitative structural characterization of the melting behavior of isotactic polypropylene, $J$. Polym. Sci., 13, 1417-1446 (1975). DOI: $10.1002 /$ pol.1975.180130713

[63] G. Guerra, V. Petraccone, P. Corradini, C. De-Rosa, R. Napolitano, B. Pirozzi, G. Giunchi, Crystalline order and melting behavior of isotactic polypropylene ( $\alpha$ form), $J$. Polym. Sci. Polym. Phys., 22, 1029-1039 (1984). DOI: $10.1002 /$ pol.1984.180220608

[64] Y. S. Yadav, P. C. Jain, Melting behaviour of isotactic polypropylene isothermally crystallized from the melt, Polymer, 27, 721-727 (1986).

DOI: https://doi.org/10.1016/0032-3861(86)90130-8 
[65] A. Sorrentino, R. Pantani, G. Titomanlio, Kinetics of melting and characterization of the thermodynamic and kinetic properties of syndiotactic polystyrene, J. Polym. Sci. Part B: Polym. Phys., 45, 196-207 (2007). DOI: $10.1002 /$ polb.21039

[66] S. Z. D. Cheng, J. J. Janimak, A. Zhang, Isotacticity effect on crystallization and melting in polypropylene fractions. 1. Crystalline structures and thermodynamic property changes, Polymer, 32, 648-655 (1991). DOI: https://doi.org/10.1016/0032-3861(91)90477-Z

[67] G. S. Venkatesh, A. Deb, A. Karmarkar, S. S. Chauhan Effect of nanoclay content and compatibilizer on viscoelastic properties of montmorillonite/polypropylene nanocomposites, Mater. Des., 37, 285-291 (2012). DOI: https://doi.org/10.1016/j.matdes.2011.12.034

[68] Y. Q. Zhanga, J. H. Leeb, H. J. Jangb, C. W. Nahb, Preparing PP/clay nanocomposites using a swelling agent, Composites: Part B, 35, 133-138 (2004). DOI: https://doi.org/10.1016/S1359-8368(03)00068-4

[69] S. Mohanty, S. K. Nayak, Effect of clay exfoliation and organic modification on morphological, dynamic mechanical, and thermal behavior of melt-compounded PA6 nanocomposites, Polym. Comp. 28, 153-162 (2007). DOI: $10.1002 /$ pc.20284

[70] S. K. Sharma, S. K. Nayak, Surface modified clay/polypropylene (PP) nanocomposites: effect on physico-mechanical, thermal and morphological properties, Polym. Degrad. Stabil., 94, 132-138 (2009). DOI: https://doi.org/10.1016/j.polymdegradstab.2008.09.004

[71] S. G. Lei, S. V. Hoa, M. T. Ton-That, Effect of clay types on the processing and properties of polypropylene nanocomposites, Compos. Sci. Technol., 66, 1274-1279 (2006). DOI: https://doi.org/10.1016/j.compscitech.2005.09.012

[72] S. M. Lai, W. C. Chen, X. S. Zhu, Melt mixed compatibilized polypropylene/clay nanocomposites: Part 1 - The effect of compatibilizers on optical transmittance and mechanical properties, Composites Part A, 40, 754-765 (2009).

DOI: https://doi.org/10.1016/j.compositesa.2009.03.006
[73] L. Raka, G. Bogoeva-Gaceva, K. Lu, J. Loos, Characterization of latex based isotactic polypropylene/clay nanocomposites, Polymer, 50, 3739-3746 (2009). DOI: https://doi.org/10.1016/j.polymer.2009.05.044

[74] R. D. K. Misra, Q. Yuan, P. K. C. Venkatsyrya, Mechanics of nanoscale surface deformation in polypropylene-clay nanocomposite, Mech. Mater., 45, 103-116 (2012).

DOI: https://doi.org/10.1016/j.mechmat.2011.10.006.

[75] S. Hambir, N. Bulakh, J. P. Jog, Polypropylene/Clay nanocomposites: Effect of compatibilizer on the thermal, crystallization and dynamic mechanical behavior, Polym. Eng. Sci., 42, 1800-1807 (2002). DOI: $10.1002 /$ pen.11072

[76] S. K. Samal, S. K. Nayak, S. Mohanty, Polypropylene Nanocomposites: Effect of organo-modified layered silicates on mechanical, thermal \& morphological performance, J. Thermoplast. Compos. Mater., 21, 243-263 (2008). DOI: https://doi.org/10.1177/0892705708089476

[77] S. Yang, J. T. Tijerina, V. S. Diaz, K. Hernandez, K. Lozano, Dynamic mechanical and thermal analysis of aligned vapor grown carbon nanofiber reinforced polyethylene, Composite Part B, 38, 228-235 (2007). DOI: https://doi.org/10.1016/j.compositesb.2006.04.003

[78] P. Maiti, P. H. Nam, M. Okamoto, N. Hasegawa, A. Usuki, Influence of crystallization on intercalation, morphology, and mechanical properties of polypropylene/clay nanocomposites, Macromolecules, 35, 2042 2049 (2002). DOI: 10.1021/ma010852z

[79] K. Prashantha, M. F. Lacrampe, P. Krawczak, Processing and characterization of halloysite nanotubes filled polypropylene nanocomposites based on a masterbatch route: effect of halloysites treatment on structural and mechanical properties, EXPRESS Polym. Lett., 5 (4), 295-307 (2011).

DOI: 10.3144/expresspolymlett.2011.30 